\title{
Prenatal Radiation Exposure: Dose Calculation
}

\section{Pränatale Strahlenexposition: Dosisermittlung}

Authors

Affiliations
C. Scharwächter ${ }^{1}$, A. Röser ${ }^{2}$, C. A. Schwartz ${ }^{1}$, P. Haage ${ }^{1}$

Department of Diagnostic and Interventional Radiology, HELIOS Klinikum Wuppertal, University Hospital Witten/Herdecke, Wuppertal, Germany

2 Department of Radiotherapy and Radio-Oncology, HELIOS Klinikum Wuppertal, University Hospital Witten/Herdecke, Wuppertal, Germany

\section{Key words}

health policy and practice

radiation effects

radiation safety

pregnancy received $\quad 6.6 .2014$

accepted $\quad 8.12 .2014$

Bibliography

Dol http://dx.doi.org/

10.1055/s-0034-1398817

Published online: 6.3.2015

Fortschr Röntgenstr 2015; 187:

338-346 @ Georg Thieme

Verlag KG Stuttgart · New York .

ISSN 1438-9029

Correspondence

Dr. Christian Scharwächter

Klinik für diagnostische und interventionelle Radiologie,

HELIOS-Klinikum Wuppertal,

Klinikum der Privaten

Universität Witten/Herdecke

Heusnerstr. 22

42283 Wuppertal

Germany

Tel.: ++ 49/2 02/8962105

Fax: ++49/2 02/8961751

christian.

scharwaechter@helios-kliniken. de

\section{Abstract}

The unborn child requires special protection. In this context, the indication for an X-ray examination is to be checked critically. If thereupon radiation of the lower abdomen including the uterus cannot be avoided, the examination should be postponed until the end of pregnancy or alternative examination techniques should be considered. Under certain circumstances, either accidental or in unavoidable cases after a thorough risk assessment, radiation exposure of the unborn may take place. In some of these cases an expert radiation hygiene consultation may be required. This consultation should comprise the expected risks for the unborn while not perturbing the mother or the involved medical staff.

For the risk assessment in case of an in-utero $\mathrm{x}$-ray exposition deterministic damages with a defined threshold dose are distinguished from stochastic damages without a definable threshold dose. The occurrence of deterministic damages depends on the dose and the developmental stage of the unborn at the time of radiation.

To calculate the risks of an in-utero radiation exposure a three-stage concept is commonly applied. Depending on the amount of radiation, the radiation dose is either estimated, roughly calculated using standard tables or, in critical cases, accurately calculated based on the individual event. The complexity of the calculation thereby increases from stage to stage. An estimation based on stage one is easily feasible whereas calculations based on stages two and especially three are more complex and often necessitate execution by specialists.

This article demonstrates in detail the risks for the unborn child pertaining to its develop- mental phase and explains the three-stage concept as an evaluation scheme. It should be noted, that all risk estimations are subject to considerable uncertainties.

- Radiation exposure of the unborn child can result in both deterministic as well as stochastic damage und hitherto should be avoided or reduced to a minimum.

- In case of radiation a suitable hygiene consultation may be necessary.

- For risk assessment a three-stage concept is applied, which, depending on the radiation exposure, estimates or calculates the dose for the unborn child.

- The radiologist plays a crucial role as a competent advisor and provider of reliable expert information.

\section{Citation Format:}

- Scharwächter C, Röser A, Schwartz CA et al. Prenatal Radiation Exposure: Dose Calculation. Fortschr Röntgenstr 2015; 187: 338346

\section{Zusammenfassung}

$\nabla$

Embryo und Fetus bedürfen eines besonderen Schutzes. In diesem Kontext ist die Notwendigkeit einer Röntgenuntersuchung besonders kritisch zu prüfen. Bei einer nicht vermeidbaren Mitbestrahlung des Unterbauches und damit des Uterus, sollte die Untersuchung bis zum Ende der Schwangerschaft verschoben oder die Möglichkeit alternativer Verfahren erwogen werden. Unter speziellen Umständen kann es jedoch, entweder inzidentell oder nach reiflicher Risikoabwägung gezielt, zu einer Röntgenuntersuchung und konsekutiv zu einer Strahlenbelastung des Ungeborenen kommen. In diesem Fall kann eine strahlenhygienische Beratung erforderlich werden. Diese enthält die zu erwartenden Risiken für das Ungeborene, ohne unnötige Ängste und Sorgen sowohl bei der 
Schwangeren, als auch bei behandelnden Kollegen zu induzieren. Für die Risikobewertung werden im Falle einer Exposition in utero deterministische Strahlenschäden mit einer definierbaren Schwellendosis und stochastische ohne Schwellendosis differenziert. Das Auftreten von deterministischen Schäden ist zusätzlich zur Dosis vom Entwicklungsstadium des Ungeborenen zum Zeitpunkt der Strahlenexposition abhängig.

Als Bewertungsschema hat sich im Falle einer Strahlenexposition in utero ein dreistufiges Konzept bewährt. In Abhängigkeit der Expositionsausprägung wird entweder eine Abschätzung der Dosis bzw. eine grobe Berechnung anhand von Rechenmodellen vorgenommen oder es erfolgt im ausgeprägtesten Fall eine auf den Einzelfall bezogene Berechnung so exakt wie möglich. Die Komplexität der Bestimmung nimmt dabei mit jeder einzelnen Stufe zu. Während eine Abschätzung nach Stufe eins normalerweise problemlos machbar ist, ist eine Berechnung nach Stufe zwei und insbesondere drei komplex und oft nur von Spezialisten durchführbar.

Im folgenden Artikel werden die Risiken für das Ungeborene in Abhängigkeit von den verschiedenen Entwicklungsphasen differenziert dargestellt und das Drei-Stufen-Konzept als Bewertungsschema näher erläutert. Hierbei ist zu berücksichtigen, dass die entsprechenden Risikoschätzungen mit nicht unerheblichen Unsicherheiten behaftet sind.

\section{Introduction}

$\nabla$

In every organism, ionizing radiation can cause both deterministic as well as stochastic damage. The prenatal phase is a particularly vulnerable period of time [1]. Prior to every planned application of ionizing radiation it must be determined whether the patient is pregnant. Before every examination using ionizing radiation on a pregnant patient, sufficient protections must be employed, such as shielding measures, in order to avoid radiating the lower abdomen and uterus. In individual cases, the uterus of a pregnant patient might receive a relevant radiation dosage; this may be inadvertent in instances of an unknown pregnancy, or as a result of an urgent medical indication such as a potentially life-threatening situation. There is considerable uncertainty in both the general population as well among non-radiologist physicians regarding action following such radiation exposure. Thus, the radiologist plays a crucial role as a competent advisor and provider of reliable expert information in this difficult patient situation.

This article is intended to provide assistance to physicians prior to or after a pregnant patient is exposed to radiation. First, possible effects of prenatal radiation exposure will be discussed in relation to the level of maturity of the embryo; in conclusion, the "three-level concept" for risk assessment of the unborn child and related recommendation for action will be presented. With respect to the three-level concept, there will also be a discussion of how the uterine dose can be estimated, or if needed, calculated. Since the desires of the affected patient are crucial with respect to subsequent consequences, there are no compulsory guidelines in this regard; however concrete recommendations have been proposed for the patient as a function of the applied dosage which are described at the end.

The article is based on the "DGMP and DRG Report on Prenatal Radiation Exposure due to medical Indications," last revised in 2002 [2], as well as DIN standards identified here; the current literature has likewise been included. Since the DGMP and DRG (German Society for Medical Physics/German X-ray Society) report was written, studies of long-term consequences of the use of atomic weapons at the end of the Second World War as well as of the Chernobyl catastrophe have been published [3 - 6]. In 2011, the nuclear accident at Fukushima took place. Initial studies of affected human beings as well as various animal populations have been published [7 - 11]. Of particular interest are comparisons with earlier events which have somewhat varying results due to differences in how they unfolded, yet which can offer additional insight nonetheless [7, 10, 11] (see below). In addition, psychological factors and their effects on births have been investigated with respect to Fukushima [12].

\section{Possible effects after prenatal radiation exposure}

$\nabla$

Prenatal development of a human being is essentially influenced by three processes: cell proliferation, cell differentiation and cell migration. All three processes can be damaged by ionizing radiation; therefore the entire prenatal phase must be considered especially sensitive to irradiation. Both the extent as well as the type of damage vary in relation to the developmental phase of the embryo or fetus. Prenatal development is generally divided into three phases: (1) pre-implantation phase which extends up to two weeks post-conception (p.c.), (2) organ-formation phase which extends from approx. the second to the eighth week p.c., and (3) fetal phase which extends from the eighth to the 39th week p.c. The potential injuries, their risk and estimated dose thresholds can be found in $\bullet$ Table 1 as well in the discussion below.

Since for obvious reasons no direct research data can be collected, in the following discussion it should be kept in mind that all data is subject to uncertainty. This is due, for example, to assumptions based on animal experiments or investigations applied to humans, or extrapolation of high dose values to lower values. However, in the past, threshold values as well as risk coefficients for injury to the embryo or fetus have been defined. The use of these values provides a general estimate of the occurrence of various biological effects, taking into account the dosage level of the exposure. Based on this, it is possible to provide a risk assessment to the pregnant patient as part of a pending or completed diagnostic examination, a therapeutic measure, or possible consideration of termination of the pregnancy. The following dosage values relate to the uterus dose equivalent $\mathrm{H}_{\mathbf{U}}$.

\subsection{Effects during implantation phase}

The pre-implantation phase is subject to the "all or nothing" rule when it comes to injury [18]. This means that in the event of sufficiently severe injury, the implantation fails and the embryo dies, or, if the damage is below a certain threshold, implantation of the blastocyst occurs without further injury. In general pregnancy is not detected at this stage, and the failed implantation is not recognized as such. Radiation doses above $100 \mathrm{mSv}$ are considered the lower threshold for failed implantation. Above this dose an additional risk of $0.1 \%$ per $\mathrm{mSv}$ is presumed (risk coefficient 
Table 1 Summary of biological effects of prenatal radiation exposure taking in account time point of exposure related to conception as well as the threshold value of risk. The spontaneous risk in the population is offered as a comparison - where comparable $[2,13-17]$.

\begin{tabular}{|c|c|c|c|c|}
\hline effect & time period p.c. & lower threshold & $\begin{array}{l}\text { risk in \%/mSv above } \\
\text { the threshold }\end{array}$ & $\begin{array}{l}\text { spontaneous risk } \\
\text { in the population }\end{array}$ \\
\hline $\begin{array}{l}\text { death during implantation } \\
\text { phase }\end{array}$ & $1^{\text {st }}-2^{\text {nd }}$ week & $100 \mathrm{mSv}$ & $0.1 \% / \mathrm{mSv}$ & $30 \%$ \\
\hline malformation & $2^{\text {nd }}-8^{\text {th }}$ week & $100 \mathrm{mSv}$ & $0.05 \% / \mathrm{mSv}$ & $6.7 \%^{1 *}$ \\
\hline severe mental retardation & $\begin{array}{l}8^{\text {th }}-15^{\text {th }} \text { week } \\
16^{\text {th }}-25^{\text {th }} \text { week }\end{array}$ & $\begin{array}{l}300 \mathrm{mSv} \\
300 \mathrm{mSv}\end{array}$ & $\begin{array}{l}0.04 \% / \mathrm{mSv} \\
0.01 \% / \mathrm{mSv}\end{array}$ & Normal Gauss distribution \\
\hline IQ reduction & $\begin{array}{l}8^{\text {th }}-15^{\text {th }} \text { week } \\
16^{\text {th }}-25^{\text {th }} \text { week }\end{array}$ & $\begin{array}{l}\text { above } 0 \mathrm{mSv} \text { (no threshold } \\
\text { value) }\end{array}$ & $\begin{array}{l}0.03 \% / \mathrm{mSv} \\
0.01 \% / \mathrm{mSv}\end{array}$ & Normal Gauss distribution \\
\hline malignant disorders & total pregnancy & $\begin{array}{l}\text { above } 0 \mathrm{mSv} \text { (no threshold } \\
\text { value) }\end{array}$ & $0.006 \% / \mathrm{mSv}$ & $\begin{array}{l}50.7 \%(\text { male })^{2} \\
42.8 \%(\text { female })^{2}\end{array}$ \\
\hline heritable defects & total pregnancy & $\begin{array}{l}\text { above } 0 \mathrm{mSv} \text { (no threshold } \\
\text { value) }\end{array}$ & $\begin{array}{l}0.003 \% / \mathrm{mSv} \text { (male) } \\
0.001 \% / \mathrm{mSv} \text { (female) }\end{array}$ & $2 \% / g e n e r a t i o n$ \\
\hline
\end{tabular}

1 Prevalence [15].

${ }^{2}$ Lifetime risk in 2008 [16].

$\left.1 \mathrm{~Sv}^{-1}\right)$. Malformations resulting from damage during the pre-implantation phase occur rarely when there is a corresponding parental predisposition, as shown in animal experimentation [19-24].

\subsection{Effects during organ formation phase}

At certain dose levels, radiation exposure during the organ formation phase can trigger functional disorders, growth inhibition or organ malformations. Likewise, approx. $100 \mathrm{mSv}$ is considered the lower threshold value for the induction of such changes. Animal studies have determined that above the threshold value, the risk of occurrence of fetal malformations increases by about $0.05 \%$ per $\mathrm{mSv}$ (risk coefficient $\left.0.5 \mathrm{~Sv}^{-1}\right)$. This value is also accepted to apply to humans in the organ formation period between the second and eighth week of gestation. At approx. $200 \mathrm{mSv}$, the fetal malformation risk is assumed to double. A reduction of head circumference in children exposed to in utero irradiation above $500 \mathrm{mSv}$ could be determined among survivors of atomic bomb explosions at Hiroshima and Nagasaki, as well as after the catastrophe at Chernobyl $[3,4,25,26]$. Possibly due to a generally lower radiation leak and rapid evacuation measures after the accident at Fukushima in 2011, there was no statistically verifiable increase in deformations among humans [7]. However, typical morphological and genetic changes could be shown among animal life in the disaster area $[8,9]$.

\subsection{Effects during fetal phase}

Formation of the central nervous system is in the foreground during the last six months of fetal development. Since this period is relatively long, injuries are relatively frequent in this phase. Especially sensitive are the periods from the 8 th to the 15th week and from the 16th to the 25th week. Exposure above the threshold dose can result in substantial mental retardation. The threshold value is $300 \mathrm{mSv}$ from the 8 th to the 25 th week. Above this value there is an additive risk of approx. $0.04 \%$ per mSv (risk coefficient $0.4 \mathrm{~Sv}^{-1}$ ) for weeks 8 to 15 , and $0.01 \%$ per $\mathrm{mSv}$ (risk coefficient $0.1 \mathrm{~Sv}^{-1}$ ) for weeks 16 to 25 . In addition to severe mental retardation, a decrease in intelligence quotient (IQ) among affected children can be observed [27, 28]. The existence of a threshold dose is unclear; the possible expected reduction of intelligence is so minimal in the low dose range that it is not measurable. Based on studies of atomic bomb survivors in Japan, it was determined that radiation exposure during the 8 th to the 15 th weeks resulted in a reduction of about 30 IQ points per Sv. Radiation exposure during weeks 16 to 25 was reflected in a reduction of approx. 10 IQ points per Sv [5, 29-31].

\subsection{Malignant disorders after in utero exposure}

In addition to the previously described deterministic radiation damage at a definable threshold dose, stochastic radiation damage may also occur. When taking into account radiation protection, it is presumed that the risk of the occurrence of such injuries in these cases increases linearly with the dose regardless of any existing threshold dosage. This type of stochastic dose response is assumed for the induction of malignant disorders. However, the available data is somewhat contradictory. While in animal experiments [6] and retrospective studies, particularly the Oxford study $[1,32]$ as well as studies of atomic bomb survivors [33], a significant increase in the occurrence of leukemia and other malignant tumors could be demonstrated; such occurrences, at least for leukemia, could not be confirmed for survivors of the accidents at Chernobyl and Fukushima [3, 10, 11]. Thus, due to a number of different factors, the underlying events have only limited comparability. For example, various absorption mechanisms are discussed - primary extracorporeal radiation at Hiroshima and primary intracorporeal absorption of radioactive iodide at Chernobyl and Fukushima [11]. Various cohort studies have demonstrated a decreasing tumor risk with increasing age [33]. Interestingly, low doses of radiation have been shown to provide protection against tumors as well as life-prolonging effects; this is based on studies of cohorts of atomic bomb survivors, mouse experiments as well as those exposed to naturallyoccurring radiation. This is referred to as radiation hormesis [34-36]. In general, the presumption is that there is susceptibility to radiation during the entire prenatal gestation period without a specified threshold level. Based on estimates, cancer mortality is approx. $0.006 \%$ per $\mathrm{mSv}$ ( $6 \%$ per Sv) $[3,37,38]$. The first trimester of the prenatal phase is possibly the most susceptible; however, an exact assess- 
ment of the relative risk during individual phases of gestation cannot be ascertained based on available data.

\subsection{Heritable defects after in utero exposure}

A stochastic dose-effect relationship is presumed for the occurrence of heritable defects, analogous to the emergence of malignant disorders. There is no data for humans regarding radiation-induced genetic changes. Animal experiments indicated that the induction of genetic damage is possibly lower prenatally than post-natally. This is due to an increased regeneration capacity during early gestational phases. Based on data obtained from animal experiments, the risk of induction of a genetic defect is approx. $0.0003 \%$ per $\mathrm{mSv}(0.3 \%$ per Sv) for male fetuses and about $0.0001 \%$ per $\mathrm{mSv}(0.1 \%$ per Sv) for female fetuses [39-41].

\section{The three-level concept for determining uterine dosage \\ $\nabla$}

Previous discussions make it clear that sufficiently strong radiation exposure will have a seriously damaging effect on the fetus.

After radiation exposure during a pregnancy, in order to determine the risk and extent of radiation-induced damage to the fetus, the attending physician or medical physics expert (MPE) must determine the equivalent dose $\mathrm{H}_{U}$ in the uterus, considered representative for the degree of exposure of the embryo or fetus. Decisions regarding further action and counseling of the pregnant patient depend on the level of the ascertained uterine equivalent dose

Unlike radiotherapeutic and nuclear medical applications in which the uterine dose in the event of a possible patient pregnancy can be primarily integrated into therapeutic planning using a treatment planning system and tabular distribution models taking into account the administered radionuclides, corresponding procedures are absent in the area of X-ray diagnostics. Instead, a three-level concept was established for the latter circumstance, the individual steps of which will be explained below. The determination of uterine dose during radiotherapeutic and nuclear medical applications is based on the statements of the joint report of the DGMP and DRG [2].

Prior to the actual employment of the three-level concept, the determination of the time period between conception and exposure is of prime importance. If this can be indicated with certainty to be less than 10 days, then according to the discussion in section 2.1, no further dose assessment is required, since the all-or-nothing rule applies (see above). If this cannot be reliably ascertained, then the examined body region as well as the examination method used are decisive for further action.

When low-dose projection radiographic procedures are used (conventional X-ray), additional assessment is only necessary if the unborn child is located in the useful beam. In all other instances, the lower threshold value cannot be reached with normal equipment use. For radiation-intensive procedures, particularly $\mathrm{CT}$, a further assessment is necessary if the uterus is physically located in the vicinity of the region to be examined without being irradiated itself. This assessment can be omitted in cases of examinations of areas far removed from the uterus, such as the skull. The exact calculation of the uter- ine equivalent dose is complex. In order to keep the number of complex calculations by medical physicists to a minimum, the determination of the uterine dose for diagnostic radiology is performed in three gradations, with increasing complexity, depending on the extent of required radiation exposure.

Level I: General assessment of the uterine dose based on tables, Level II: Assessment of the uterine dose using examination parameters and typical device and patient data,

Level III: The uterine equivalent dose is calculated based on individual examination parameters and device- and patient-specific data.

When this concept is applied, it should be kept in mind that the levels should be followed sequentially, and the amount of the dose established in the related level determines the application in the next higher level as well as the implications for counseling the pregnant patient.

\subsection{General assessment of the uterine dose (Level I)}

In a number of unintended or even necessary radiation exposures, the applied dose remains relatively low, resulting in no predictable consequences for the pregnant patient. According to figures provided by the German Federal Office for Radiation Protection, the uterine dose for approx. threequarters of examinations during pregnancy is below $5 \mathrm{mSv}$ [42]. The purpose of the initial general assessment using tables is to reduce extensive exact calculations to those actually required for the individual case. The bases for this are standardized basic parameters for the examination which may lead to realistic yet higher dose values, to avoid a false sense of security [2].

\subsubsection{Radiography/fluoroscopy}

With respect to the equipment, the uterine dose is dependent on the parameters set for the examination. Certain assumptions for the equipment parameters are established to permit a tabular assessment in the initial level ( 0 Table 2 ). In addition to beam quality which is determined by the tube voltage and filtering installed in the equipment, the dose registered on the uterus is influenced by the dose requirement on the image receptor and beam attenuation caused by grids and other irradiated media.

Otherwise the dose is essentially determined by the thickness of the patient. Any positional anomalies of the uterus are not considered in this instance; instead the presumption for a.p.images is that the uterus is $3 / 10$ of the patient diameter, and lies in the center for lateral images. Three irradiated body thicknesses are always listed in the table to account for differences in patient constitution.

$\mathrm{X}$-ray dosage values based on these assumptions are shown in 0 Table 3, the dose rate values for fluoroscopic examinations are contained in 0 Table 4. However, the actual technical frequency range of X-ray and fluoroscopic equipment is wide so that the actual dose values vary correspondingly. The foundational tables are based on the worst case. If, according to the measured values, the dose or dose rate requirement during the acceptance test are presumed to be less than indicated in $\bullet$ Table 2 in a concrete case, the tabular values can be reduced proportionally. The same applies to the equipment attenuation factor. Since the worst case is also presumed for fluoroscopic equipment, only the fluoroscopy time in which the uterus was exposed to the primary beam should be used for calculation [2]. 
Table 2 Underlying radiographic/fluoroscopic. Technical parameters used as benchmark data for general dose assessment according to Level I of the threelevel concept [2].

\begin{tabular}{|ll|}
\hline beam quality & $70-80 \mathrm{kV}$ \\
\hline filter & $2.5 \mathrm{~mm} \mathrm{Al}$ \\
\hline image receptor dose requirement for film-screen systems & $5 \mu \mathrm{Gy} /$ image \\
\hline image receptor dose requirement for digital I. I. images & $2 \mu \mathrm{Gy} / \mathrm{image}$ \\
\hline image receptor dose requirement for DSA images & $10 \mu \mathrm{Gy} /$ image \\
\hline dose rate at image intensifier input during fluoroscopic examinations & $0.6 \mu \mathrm{Gy} / \mathrm{s}$ at $25 \mathrm{~cm}$ I. I. diameter \\
\hline grid and tabletop attenuation & equipment attenuation factor 4 \\
\hline
\end{tabular}

Table 3 Highest value of uterine equivalent dose in $\mathrm{mSv}$ of radiographic and fluoroscopic images for assessment according to Level I of the three-level concept [2].

\begin{tabular}{|c|c|c|c|c|c|c|c|}
\hline \multirow[b]{2}{*}{ projection } & \multicolumn{7}{|c|}{ uterine equivalent dose in $\mathrm{mSv}$ per image } \\
\hline & a.p. & & & p.a. & & & lateral \\
\hline \multirow{2}{*}{ constitution } & thin & normal & thick & thin & normal & thick & normal \\
\hline & $17 \mathrm{~cm}$ & $22 \mathrm{~cm}$ & $26 \mathrm{~cm}$ & $17 \mathrm{~cm}$ & $22 \mathrm{~cm}$ & $26 \mathrm{~cm}$ & $36 \mathrm{~cm}$ \\
\hline film-screen system grid image & 2 & 3 & 5 & 1 & 1.5 & 2.5 & 4 \\
\hline digital I. I. image & 1 & 1.5 & 2 & 0.5 & 0.8 & 1 & 2 \\
\hline DSA image & 4 & 6 & 10 & 2 & 3 & 5 & 8 \\
\hline
\end{tabular}

Table 4 Highest value of uterine equivalent dose in $\mathrm{mSv} / \mathrm{min}$ during fluoroscopic examinations using an image intensifier-television system for assessment according to Level I of the three-level concept [2].

\begin{tabular}{|c|c|c|c|c|c|c|c|}
\hline \multirow[b]{2}{*}{ projection } & \multicolumn{7}{|c|}{ uterine equivalent dose in mSv per minute } \\
\hline & a.p. & & & p. a. & & & lateral \\
\hline constitution & thin & normal & thick & thin & normal & thick & normal \\
\hline & $17 \mathrm{~cm}$ & $22 \mathrm{~cm}$ & $26 \mathrm{~cm}$ & $17 \mathrm{~cm}$ & $22 \mathrm{~cm}$ & $26 \mathrm{~cm}$ & $36 \mathrm{~cm}$ \\
\hline FL with I. I. television system & 16 & 24 & 40 & 8 & 12 & 20 & 32 \\
\hline
\end{tabular}

\subsubsection{Computed tomography}

Computed tomography (CT) uses a different approach compared to radiographic examination. If the uterus was positioned in the direct examination field, then conservative general assessment always results in values above $20 \mathrm{mSv}$. In this case, a more precise calculation is required (see section 2.4). This is also required if the uterus was not positioned directly within, but rather adjacent to, the examination volume. Decisive here is the dose required per slice or rotation determined by the tube current-time product (mAs product) $[2]$.

If, on the other hand, an examination was performed on a body region far removed from the uterus, dose values in - Table 5 apply to the general assessment of all CT examinations. The values shown in the table are based on $100 \mathrm{mAs}$ per slice or revolution. These values are converted applying the rule of three to the mAs product [2].

\subsubsection{Example 1}

A patient in the fourth week of pregnancy with a sagittal diameter of $21 \mathrm{~cm}$ receives an emergency X-ray of the thorax on two planes as well as of the abdomen on one plane, and then is subjected intraoperatively to an additional fluoroscopy of 3 minutes, during which the pelvis was exposed for 30 seconds.

\section{Assessment}

Only the abdominal image pertains to the general assessment of the X-ray images, since only the uterus lay in the
Table 5 Values for assessment of uterine equivalent dose in $\mathrm{mAs} /$ slice or rotation during computed tomography corresponding to an assessment according to Level I of the three-level concept [2].

\begin{tabular}{|c|c|}
\hline tube voltage (kV) & $\begin{array}{l}\text { uterine equivalent dose in } \mathrm{mSv} \text { at } 100 \mathrm{~mA} / \text { slice } \\
\text { or rotation }\end{array}$ \\
\hline 80 & 1.0 \\
\hline 120 & 2.0 \\
\hline
\end{tabular}

main beam in this case. According to $\odot$ Table 3 the equivalent dose for a normally constituted patient using an image with a film/screen system is $3 \mathrm{mSv}$.

Only the abdominal image is relevant for the general assessment of the X-ray images, since only the uterus lay in the main beam in this case. According to $\odot$ Table 4 the equivalent dose rate for a normally constituted patient is $0.5^{*}$ $24 \mathrm{mSv}=12 \mathrm{mSv}$.

In total, the general assessment in our example according to Level I yields a uterus equivalent dose value of $15 \mathrm{mSv}$. Since the limit of $20 \mathrm{mSv}$ is not exceeded, a more exact calculation can be omitted. The assessment should be documented in the patient's file. Refer to section $\mathbf{2 . 5}$ for the resulting recommendations for the pregnant patient.

\subsection{Uterine dose calculation (Levels II and III)}

Determination of the uterine dose according to Levels II and II is more complicated and is generally calculated with the help of a medical physicist. The differences between Levels 
II and III lie in the source data used to determine the uterine dose. In Level II, equipment-specific data from relevant tables is sufficient for calculation; in the third level, equipment-specific variables are used for the related examination, e. g. taken from the logs of the acceptance test. Further, Level III takes into account the individual patient geometry as well as exposure conditions.

\subsubsection{Radiography/fluoroscopy}

In order to calculate the uterine dose apart from a pure tabular assessment, it is necessary to determine the incident dose $\mathrm{K}_{\mathrm{E}}$. This can be performed in two ways. Using the socalled source concept, the incident dose is calculated directly from the examination parameters. Critical in this instance is the characteristic dose rate of the X-ray tube measured in air which is dependent on the selected tube voltage and total filtering, and which as a rule is measured at a fixed focal length. Based on the imaging or fluoroscopy time as well as the focus-skin distance, the incident dose can be calculated according to $\bullet$ Fig. 1 a.

In contrast, when the image receptor concept is applied, the dose incidence is estimated based on the dose requirement on the image receptor taking into account attenuation factor S ( $\odot$ Fig. 1b).

When newer equipment is used, and especially during fluoroscopic examinations, the incident dose can also be determined from the measured area dose product. However, to do this, data regarding the size of the image on the receptor as well as values for the focus-image receptor and focus-skin distance are required ( $\bullet$ Fig. 1c).

Using the known incident dose $\mathrm{K}_{\mathrm{E}}$, the uterine dose can be determined using three methods [43-46]:

a) using organ dose conversion factors from the incident dose or the dose area product of standardized examinations,

b) using the tissue-air ratio based on the incident dose and the derived tissue-energy dose at the uterus level,

c) using depth-dose organ tables from the incident dose or the surface dose of the side of the radiation entrance.

With the help of a), an average organ equivalent dose $\mathrm{H}_{\mathrm{T}}$ is obtained based on the average total mass of the uterus; using b) and c), the organ-energy dose or organ equivalent dose is obtained as a dot size. Refer to $\bullet$ Fig. 2 for the exact determination of the organ equivalent dose.

\subsubsection{Computed tomography}

Several factors are required to determine the uterine dose during $\mathrm{CT}$ examinations. On the one hand, the uterine dose depends on the average air kerma in the system axis. It is based on the integrated dose across a CT scan normalized to the nominal slice thickness; this is also called CTDI ${ }_{\text {air }}$. Further, an organ dose conversion factor is required which indicates the uterine dose (per unit of CTDI ${ }_{\text {air }}$ ) required to effect a $1 \mathrm{~cm}$ thick $360^{\circ}$ slice as a function of the distance of the related CT slice from the uterus [ $47-49]$. The individual components are then added up to a total uterine dose (o Fig. 3).

For calculations according to Level II, the average air kerma in the system axis can be taken from related tables. The values are normalized to $100 \mathrm{mAs}$ per CT slice; adaptation corresponding to the mAs product is then necessary. Calculations according to Level III use the measured and

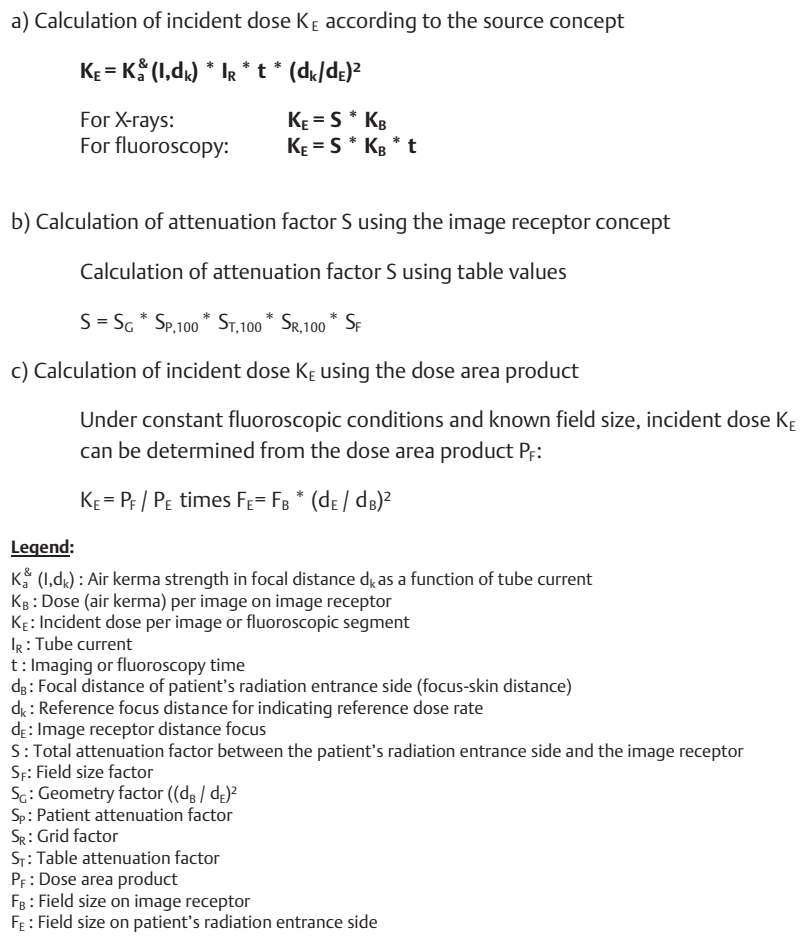

b) Calculation of attenuation factor $S$ using the image receptor concept

Calculation of attenuation factor $\mathrm{S}$ using table values

$\mathrm{S}=\mathrm{S}_{\mathrm{G}} * \mathrm{~S}_{\mathrm{P}, 100} * \mathrm{~S}_{\mathrm{T}, 100} * \mathrm{~S}_{\mathrm{R}, 100} * \mathrm{~S}_{\mathrm{F}}$

c) Calculation of incident dose $K_{E}$ using the dose area product

Under constant fluoroscopic conditions and known field size, incident dose $\mathrm{K}_{\mathrm{E}}$ can be determined from the dose area product $P_{F}$ :

$K_{E}=P_{F} / P_{E}$ times $F_{E}=F_{B} *\left(d_{E} / d_{B}\right)^{2}$

Legend:

$K_{a}^{\&}\left(I, d_{k}\right)$ : Air kerma strength in focal distance $d_{k}$ as a function of tube current

$\mathrm{K}_{\mathrm{B}}$ : Dose (air kerma) per image on image receptor

$\mathrm{K}_{\mathrm{E}}$ : Incident dose per image or fluoroscopic segment

$I_{R}:$ Tube current

. Imaging or fluoroscopy time

: Focal distance of patient's radiation entrance side (focus-skin distance)

: Reference focus distance for indicating reference dose rate

: Image receptor distance focus

: Total attenuation factor between the patient's radiation entrance side and the image receptor

: Field size factor

G: Geometry factor $\left(\left(d_{B} / d_{E}\right)^{2}\right.$

: Patient atten

: Grid factor

F: Table attenuation factor

$\mathrm{F}_{\mathrm{B}}$ : : Fieseld size on image receptor

$\mathrm{F}_{\mathrm{E}}$ : Field size on patient's radiation entrance side

Fig. 1 Determining incident dose.

documented values in the acceptance test for the specific equipment.

\section{Recommendations for the pregnant patient}

$\nabla$

Once the extent and point of time of the radiation exposure have been established, the radiologist has a crucial task to advise the pregnant patient or other medical colleagues regarding further action. In this situation it is essential to express sound, professionally competent recommendations in order to counter vague fears as well as erroneous downplaying of the situation from the outset.

The following explanations are standard recommendations based on the guidelines of the German X-ray Society; however the final decision is always up to the patient herself [2]. If the exposure to radiation - no matter the dose - definitely took place within 10 days p.c., a record of this is made by the physician; further calculation is unnecessary. The patient should be informed only as she requests to avoid unwarranted worry. Termination of the pregnancy is not discussed.

If exposure occurs more than 10 days after conception, the recommendations are oriented toward the applied dose.

If the dose lies below $20 \mathrm{mSv}$, the physician records this; additional calculation is not required, and an assessment is performed according to Level I. The patient should be informed regarding possible consequences only upon request. Termination of the pregnancy is not discussed.

If the dose is above $20 \mathrm{mSv}$, the physician records this; additional calculation is not required, and assessment according to Level II is required. If the value is below $100 \mathrm{mSv}$, the physician informs the patient regarding potential consequen- 


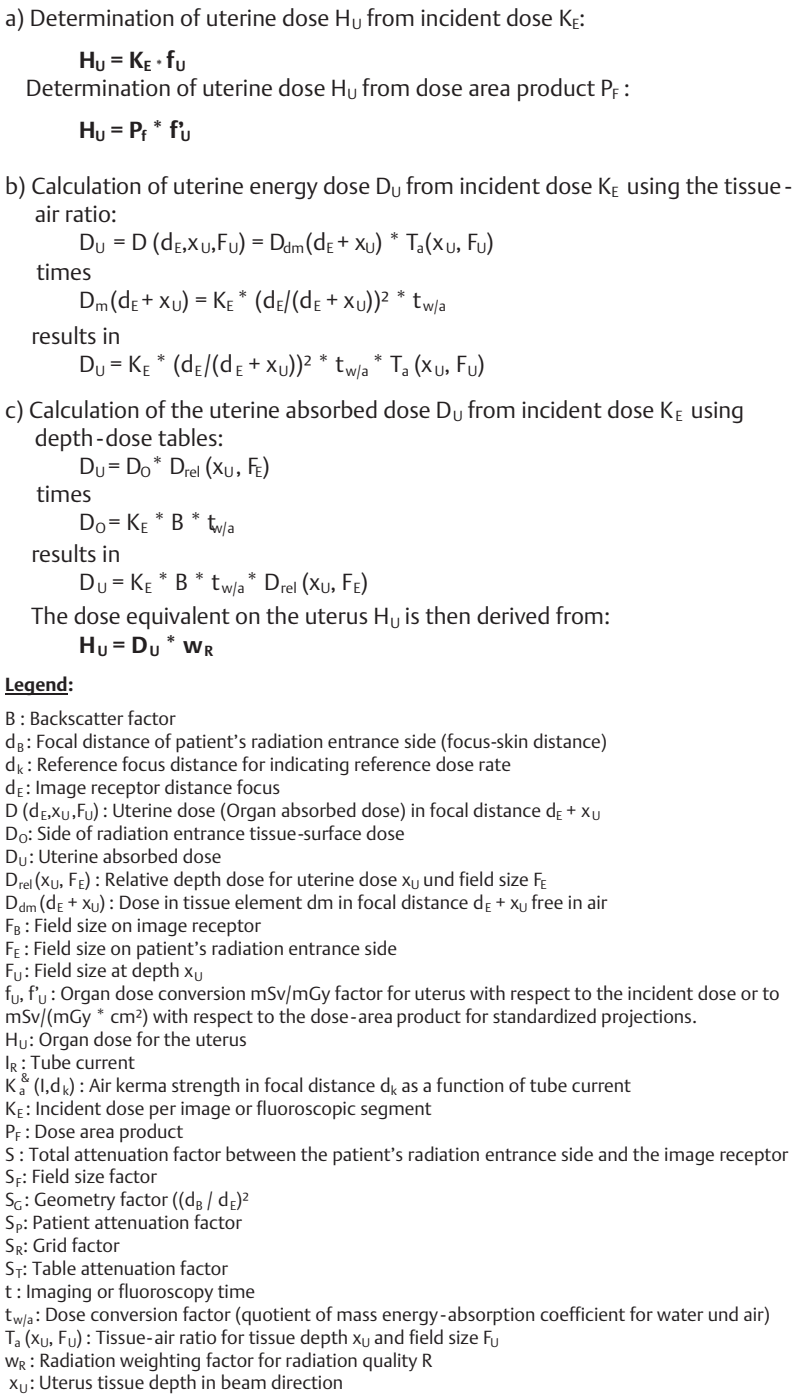

Fig. 2 Determining uterine equivalent dose.

ces, and in the discussion, the physician does not mention termination.

If a determination based on Level II is greater than $100 \mathrm{mSv}$, accurate calculation according to Level III is required. If the dose is below $100 \mathrm{mSv}$, the physician informs the patient regarding possible consequences, and in the discussion, the physician does not mention termination.

If the dose according to Level III is between 100 and $200 \mathrm{mSv}$, the physician records this; the physician informs the patient regarding possible consequences. A detailed discussion between the physician and patient takes place in which the risk of fetal damage must be weighed against the patient's desire to have a child. If termination of the pregnancy is desired, the physician supports this decision. If the dose is above $200 \mathrm{mSv}$, the physician records this; the physician informs the patient regarding possible consequences. A detailed discussion between the physician and patient likewise takes place in which the risk of fetal damage must be weighed against the patient's desire to have a child. The physician suggests termination during this discussion, as needed.
Calculating uterine dose in computed tomography

$$
H_{U}=K_{C T} * \sum_{z_{u}}^{z_{0}} f_{\text {Uterus }}(z)
$$$$
\mathrm{K}_{\mathrm{CT}}=1 / \mathrm{s} \int_{-\infty}^{\infty} K_{\mathrm{a}}(\mathrm{z}) d z
$$

$$
\mathrm{K}_{\mathrm{CT}}={ }_{100} \mathrm{~K}_{\mathrm{CT}}{ }^{*} \mathrm{I}_{\mathrm{R}} * \mathrm{t} * 0,01
$$

Legend

$\mathrm{f}_{\text {Uterus }}(\mathrm{z})$ : Organ dose conversion factor (mSv/mGy)

$\mathrm{H}_{\mathrm{u}}$ : Organ dose for the uterus

$I_{R}:$ Tube current

the system axis

roscopy time

$z_{u}, z_{0}$ : Distance of the upper and lower boundary of the examined body from the lower end of t

Fig. 3 Determining the uterine dose during $\mathrm{CT}$ examinations.

This course of action is additionally shown in $\bullet$ Fig. 4 as a flow chart.

\section{Summary}

The prenatal phase is a particularly vulnerable period for the development of deterministic as well as stochastic damage caused by the application of ionizing radiation. Therefore pregnancy represents a contraindication for the use of $\mathrm{X}$-rays. However, under special circumstances, irradiation of the fetus may occur either incidentally or after careful risk assessment. In this case, advice regarding the health risks of radiation is necessary, containing the anticipated risks for the fetus without arousing unnecessary fears and concerns on the part of both the patient and the attending physicians.

In principle a differentiation should be made between deterministic injury at a definable threshold dose and stochastic radiation damage without a threshold dose. In this case, the occurrence of deterministic damage is dependent upon the gestational age of the fetus at the time of exposure as well as the level of the dose.

A three-level concept has been shown to be effective for risk assessment of in utero irradiation during a radiological examination. Depending on the severity of the exposure, an estimate of the dose or a general assessment is made based on computer models; in the most salient cases, an exact calculation as possible is made with respect to the individual event. The complexity of the determination increases with each level. While an estimate according to level one is normally feasible without a problem, calculation according to level two and particularly level three is complex and should be performed only by an expert medical physicist.

Based on the determination of the uterine dose according to the three-level concept while taking into account the age of the fetus and relying on established threshold levels and empirical values, a largely standardized counseling approach can be used with the patient. Although it contains uncertainties, this approach provides both the pregnant woman as well as attending physicians with a basis for action which can be used for further decisions. The risk to 


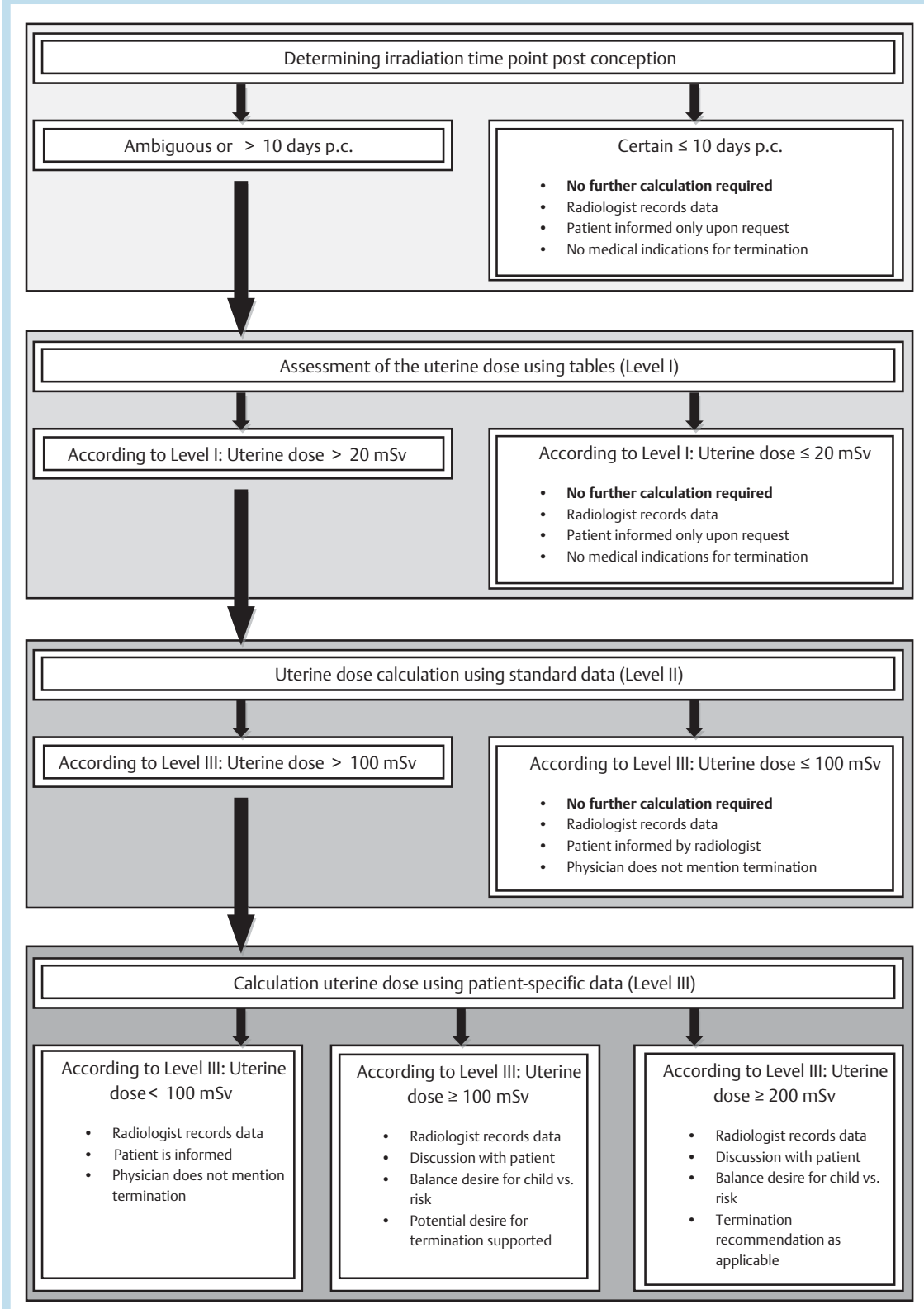

Fig. 4 Flow chart for determining radiation exposure and recommendations for subsequent consequences.

the fetus is generally low if the exposure to radiation occurs in the course of diagnosis. The uterine dose is below $5 \mathrm{mSv}$ for approx. three-quarters of examinations [31]. The physician should always explain the risks in terms of deterministic or stochastic injury compared to the related spontaneous risk of malformation. Calculations are subject to uncertainties, particularly due to the limited study opportunities, the low number of cases as well as data based on animal experiments; the pregnant patient should be made aware of this. During the evaluation, additional potential risks as well as the desire of the patient to have a child should also be taken into account. Furthermore, the results of additional diagnostics should be considered, perhaps in consultation with a human geneticist. However, the final decision should and must rest with the patient herself once she has been fully and objectively informed regarding the possible risks of irradiation.

\section{References}

1 Wakeford R. Childhood leukaemia following medical diagnostic exposure to ionizing radiation in utero or after birth. Radiat Prot Dosimetry 2008; 132: 166-174

2 DRG, DGMP. Pränatale Strahlenexposition aus medizinischer Indikation. DGMP Bericht Nr. 7: 2002

3 Preston DL, Cullings H, Suyama A et al. Solid cancer incidence in atomic bomb survivors exposed in utero or as young children. J Natl Cancer Inst 2008; 100: $428-436$

4 Wertelecki W. Malformations in a chornobyl-impacted region. Pediatrics 2010; 125: 836-843

5 Schull WJ. The children of atomic bomb survivors: a synopsis. J Radiol Prot 2003; 23: 369-384

6 Little MP. Cancer and non-cancer effects in Japanese atomic bomb survivors. J Radiol Prot 2009; 29: A43 - A59

7 Fujimori K, Kyozuka H, Yasuda S et al. Pregnancy and birth survey after the Great East Japan Earthquake and Fukushima Daiichi Nuclear Power Plant accident in Fukushima prefecture. Fukushima J Med Sci 2014; 60: $75-81$

8 Mousseau TA, Møller AP. Genetic and ecological studies of animals in Chernobyl and Fukushima. J Hered 2014; 105: 704-709

9 Taira W, Nohara C, Hiyama A et al. Fukushima's biological impacts: the case of the pale grass blue butterfly. J Hered 2014; 105: 710-722 
10 Fushiki S. Radiation hazards in children - lessons from Chernobyl, Three Mile Island and Fukushima. Brain Dev 2013; 35: 220-227

11 Takamura N, Yamashita S. Lessons from Chernobyl. Fukushima J Med Sci 2011; 57: 81-85

12 Yoshii H, Saito H, Kikuchi S et al. Report on maternal anxiety 16 months after the great East Japan earthquake disaster: anxiety over radioactivity. Glob J Health Sci 2014; DOI: 10.5539/gjhs.v6n6p1.

13 Macklon NS, Geraedts JP, Fauser BC. Conception to ongoing pregnancy: the 'black box' of early pregnancy loss. Hum Reprod Update 2002; 8: $333-343$

14 Larsen EC, Christiansen OB, Kolte AM et al. New insights into mechanisms behind miscarriage. BMC Med 2013; 11: 154

15 Queißer-Luft A, Spranger J. Fehlbildungen bei Neugeborenen. Dtsch Arztebl 2006; 103: A2464-A2471

16 RKI. Krebs in Deutschland 2007/2008. 8. Ausgabe. Berlin: Robert KochInstitut (Hrsg) und die Gesellschaft der epidemiologischen Krebsregister in Deutschland e.V. (Hrsg); 2012

17 RKI. Krebs in Deutschland 2007/2008. Berlin: Robert Koch-Institut (Hrsg) und die Gesellschaft der epidemiologischen Krebsregister in Deutschland e.V. (Hrsg); 2012; 8. Ausgabe

18 Brent RL, Bolden BT. Indirect effect of $\mathrm{x}$-irradiation on embryonic development. V. Utilization of high doses of maternal irradiation on the first day of gestation. Rad Res 1968; 36: 563-570

19 Russell LB. X-ray induced developmental abnormalities in the mouse and their use in analysis of embryological patterns. I. External and gross visceral changes. J Exp Zool 1950; 114: 345-602

20 Russell LB. X-ray-induced developmental abnormalities in the mouse and their use in analysis of embryological patterns. II. Abnormalities of the vertebral column and thorax. J Exp Zool 1956; 131: 329-395

21 Rugh R, Grupp E. Exencephalia following x-irradiation of the pre-implantation mammalian embryo. J Neuropathol Exp Neurol 1959; 18: $468-481$

22 Müller WU, Streffer $C$. Lethal and teratogenic effects after exposure to X-rays at various times of early murine gestation. Teratology 1990; 42: $643-650$

23 Jacquet $P$, de Saint-Georges L, Vankerkom J et al. Embryonic death, dwarfism and fetal malformations after irradiation of embryos at the zygote stage: studies on two mouse strains. Mutat Res 1995; 332: $73-87$

$24 \mathrm{Gu}$ Y, Kai M, Kusama T. The embryonic and fetal effects in ICR mice irradiated in the various stages of the preimplantation period. Radiat Res 1997: 147: 735 - 740

25 Wood J, Johnson KG, Omori Y. Mental retardation in children exposed in utero to the atomic bombs in Hiroshima and Nagasaki. Am J Public Health 1967; 57: $1381-1390$

26 Wood J, Keehn R, Kawamoto S. The growth and development of children exposed in utero to the atomic bombs in Hiroshima and Nagasaki. Am J Public Health 1967; 57: 1374-1380

27 Schull WJ, Otake M. Cognitive function and prenatal exposure to ionizing radiation. Teratology 1999; 59: $222-226$

28 Verheyde J, Benotmane MA. Unraveling the fundamental molecular mechanisms of morphological and cognitive defects in the irradiated brain. Brain Res Rev 2007; 53: 312-320
29 Otake M, Schull WJ. In utero exposure to A-bomb radiation and mental retardation; a reassessment. Br J Radiol 1984; 57: 409-414

30 Yamazaki JN, Schull WJ. Perinatal loss and neurological abnormalities among children of the atomic bomb. Nagasaki and Hiroshima revisited, 1949 to 1989. JAMA 1990; 264: $605-609$

31 Otake M, Schull WJ, Lee S. Threshold for radiation-related severe mental retardation in prenatally exposed A-bomb survivors: a re-analysis. Int J Radiat Biol 1996; 70: 755 -763

32 Wakeford R, Little MP. Risk coefficients for childhood cancer after intrauterine irradiation: a review. Int J Radiat Biol 2003; 79: 293-309

33 Little MP. Cancer and non-cancer effects in Japanese atomic bomb survivors. J Radiol Prot 2009; 29: A43-A59

34 Doss $M$. Evidence supporting radiation hormesis in atomic bomb survivor cancer mortality data. Dose Response 2012; 4: 584-592

35 Fornalski KW, Dobrzyński L. The cancer mortality in high natural radiation areas in poland. Dose Response 2012; 10: 541 - 561

36 Scott BR, Bruce VR, Gott KM et al. Small y-Ray Doses Prevent Rather than Increase Lung Tumors in Mice. Dose Response 2012; 10: 527 - 540

37 Ray JG, Schull MJ, Urquia ML et al. Major radiodiagnostic imaging in pregnancy and the risk of childhood malignancy: a population-based cohort study in Ontario. PloS Med 2010; 7: 1-8

38 Brent RL. Carcinogenic risks of prenatal ionizing radiation. Semin Fetal Neonatal Med 2014; 19: 203 -213

39 Benjamin SA, Lee AC, Angleton GM et al. Mortality in beagles irradiated during prenatal and postnatal development. I. Contribution of nonneoplasia diseases. Radiat Res 1998; 150: 330 - 348

40 Nakano M, Kodama Y, Ohtaki K et al. Chromosome aberrations do not persist in the lymphocytes or bone marrow cells of mice irradiated in utero or soon after birth. Radiat Res 2007; 167: 693-702

41 Brent RL, Bushberg JT, Linet $M$ et al. NCRP Report No. 174. Preconception and prenatal radiation exposure: health effects and protective guidance; 2013: 351

42 Minkov V, Nekolla EA, Nosske D et al. Nuclear-medical irradiation during pregnancy. Risk assessment for the offspring. Nuklearmedizin 2009; 48: $10-16$

43 Wachsmann F, Drexler G. Kurven und Tabellen für die Radiologie. 2. Aufl. Berlin-Heidelberg-New York: J. Springer; 1976

44 Thomasz E, Eckerl H, Drexler G. Experimental determination of conversion factors between organ doses and measured quantities for external photon irradiation. Health Phys 1985; 49: 897-905

45 Drexler G, Panzer W, Stieve FE et al. Die Bestimmung von Organdosen in der Röntgendiagnostik. 2. Aufl. Berlin: H.Hoffmann; 1993

46 Harrison J, Day P. Radiation doses and risks from internal emitters. J Radiol Prot 2008; 28: 137 -159

47 Nishizawa K, Maruyama T, Takayama $M$ et al. Determinations of organ doses and effective dose equivalents from computed tomographic examination. Br J Radiol 1991; 64: 20-28

48 Nagel HD. Strahlenexposition in der Computertomographie. ZVEI Fachverband. Frankfurt: Elektromedizinische Technik; 1999

49 Bailey TM, Vealé BL. Advanced computed tomography technology and patient dose: a literature review. Radiol Manage 2011; 33: 43 - 46 